\title{
Biology and control of the red palm mite, Raoiella indica: an introduction
}

\author{
Jorge E. Peña $\cdot$ Jan Bruin $\cdot$ Maurice W. Sabelis
}

Received: 21 April 2012/Accepted: 21 April 2012/Published online: 15 May 2012

(C) Springer Science+Business Media B.V. 2012

The plant-feeding mite family Tenuipalpidae comprises ca. 35 genera and $900+$ species (Mesa et al. 2009; Beard et al. 2012). Brevipalpus and Tenuipalpus are recognized as the genera that harbour species causing most economic damage, to a great variety of crops. This special issue of Experimental and Applied Acarology focuses on Raoiella, a genus of Tenuipalpidae that has gained economical importance in recent years and now poses new challenges to pest control. This genus should be included in the list of economically important Tenuipalpidae, especially because of the damage it inflicts on coconut palms, being a source of nutrition and income for people inhabiting the tropical world.

Most prominent among the species in this genus is the red palm mite, Raoiella indica Hirst. It is also known as coconut mite, coconut red mite, red date palm mite, leaflet false spider mite, frond crimson mite, or scarlet mite. Whereas important as a pest of coconuts, date palms and other palm species, it is also a pest of bananas in different parts of the world. Before it arrived in the New World, the mite was found in India, Philippines, Mauritius, Reunion, Malaysia, Israel and Egypt. The first report from the New World came from the Caribbean Islands: Martinique and St. Lucia in 2004, Dominica in 2005, and in 2006 Trinidad and Tobago, Guadeloupe, and Saint Martin (Kane and Ochoa 2005; Etienne and Flechtmann 2006). Damage by red palm mites was observed widespread on these islands and on various host plants, e.g. on lower leaves of coconut palm (Arecaceae) in St. Lucia (Kane and Ochoa 2006), on leaves of banana (Musaceae) in Dominica (N. Commodore, personal observation, 2005; FAO 2005) and on other plants within the Musaceae, ginger (Zingiberaceae) and bird of paradise plants (Strelitziaceae) (Etienne and Flechtmann 2006). Raoiella indica is not only found on the Carribean Islands, it has also started to spread on the mainland-for instance, it has now been reported from Florida, USA

\footnotetext{
J. E. Peña $(\bowtie)$

Department of Entomology and Nematology, Tropical Research and Education Center, University of Florida, Homestead, FL 33031, USA

e-mail: jepe@mail.ifas.ufl.edu

J. Bruin · M. W. Sabelis

IBED, Section Population Biology, University of Amsterdam, PO Box 94084, 1090 GB Amsterdam, The Netherlands
} 
(FDACS 2007), Venezuela (Vásquez et al. 2008), Colombia (Carrillo et al. 2011) and Brazil (Navia et al. 2011, Rodrigues and Antony 2011).

Initially, the extensive damage to coconut palms on the islands was thought to be due to 'lethal yellowing' (LY), a highly prevalent disease of palms in various countries of the Caribbean Basin. This confusion arose because LY infection, like red palm mite feeding, results in extensive chlorosis and yellowing of the lower leaves. However, in a very early stage, LY disease differs in that it causes coconuts of all stages to drop from the tree, it distorts the emerging inflorescences and it causes the male flowers to become dark brown. Yet another difference is that LY disease is never associated with red palm mites, which by their red colour are easily recognized on the abaxial surfaces of older foliage and which leave scaly patches of exuviae behind. Once red palm mites were recognized as the cause of the damage to the coconut palms on the islands, it became clear that they can reduce coconut production by more than $50 \%$ in the Caribbean Basin (CARDI 2010).

In the wake of the invasion of $R$. indica into the New World the need arose to bring together existing information on taxonomy (Sayed 1942), biology (Moutia 1958; Zaher et al. 1969; Jeppson et al. 1975; Gerson et al. 1983; Nagesha-Chandra and Channabassanna 1984; Sakar and Somchodhury 1989), and control (Moutia 1958; Saradamma 1973; Puttaswamy and Rangaswamy 1976; Daniel 1981; Somchoudhry and Sarkar 1987; Sakar and Somchodhury 1988; Jalaluddin and Mohanasundaram 1990; Nadarajan et al. 1990; Jayaraj et al. 1991). Although there are comprehensive compilations published on the world-wide web (a.o. FAO 2005; CARDI 2010) and in journals (Sayed 1942; Elwan 2000; Gupta 2001; Mendonca et al. 2005; PROSEA 2006; Rodrigues et al. 2007a, b; Vásquez et al. 2008; Carrillo et al. 2011), these tend to focus on the distribution, importance and current status of $R$. indica.

The need for a fuller coverage of also other topics - such as host plant range, taxonomy, phylogeny, morphology, species recognition by means of molecular techniques, dispersion and sampling techniques, population dynamics, classical biological control, natural enemies and chemical control-provided the impetus for this special issue of Experimental and Applied Acarology on Raoiella. Twenty-eight Raoiella experts took part in this attempt to assemble the existing knowledge and to pinpoint the gaps in knowledge. We hope it will also stimulate interest in the lesser known genera of the Tenuipalpidae, provide a basis for more rational control strategies, and help to identify the areas where more research is needed.

\section{References}

Beard JJ, Ochoa R, Bauchan G, Trice M, Redford A, Walters T, Mitter C (2012) Flat mites of the world. http://idtools.org/id/mites/flatmites/ (Accessed Apr 2012)

CARDI Caribbean Agricultural Research and Development Institute (2010) Natural resource management, invasive species. http://www.cardi.org/commodities-themes/natural-resource-management/ (Accessed July 2010)

Carrillo D, Navia D, Ferragut F, Peña JE (2011) First report of Raoiella indica Hirst (Acari: Tenuipalpidae) in Colombia. Fla Entomol 94:370-371

Daniel M (1981) Bionomics of the predaceous mite Amblyseius channabasavanni (Acari: Phytoseiidae), predaceous on the palm mite Raoiella indica. In: Channabasvanna GP (ed) 1st Indian symposium in acarology, April 23-25, Bangalore, India, pp 167-173

Elwan A (2000) A survey of the insect and mite pests associated with date palm trees in Al-Dakhliya region, Sultanate of Oman. Egypt J Agric Res 78:653-664

Etienne J, Flechtmann CHW (2006) First record of Raoiella indica (Hirst, 1924) (Acari: Tenuipalpidae) in Guadeloupe and Saint Martin, West Indies. Int J Acarol 32:331-332 
FAO (2005) International phytosanitary portal: official pest report Dominica (2005-11-16). Raoiella indica in the Americas. https://www.ippc.int/id/nppodm?language=en

FDACS (2007) Red palm mite infestation identified in palm gardens. Florida Department of Agriculture and Consumer Services. http://www.freshfromflorida.com/pi/pest-alerts/raoiella-indica.html (Accessed Apr 2012)

Gerson U, Venezian A, Blumberg D (1983) Phytophagous mites on date palms in Israel. Fruits 38:133-135

Gupta YN (2001) A conspectus of natural enemies of phytophagous mites and mites as potential biocontrol agents of agricultural pests in India. In: Halliday RB, Walter DE, Proctor HC, Norton RA, Colloff MJ (eds) Acarology: proceedings of the 10th international congress. CSIRO Publishing, Melbourne, pp 484-497

Jalaluddin SM, Mohanasundaram M (1990) Control of the red coconut mite Raoiella indica Hirst (Tenuipalpidae: Acari) in the nursery. Indian Coconut J 21:7-8

Jayaraj J, Natarajan K, Ramasubramanian G (1991) Control of Raoiella indica Hirst (Tenuipalpidae: Acari) on coconut with pesticides. Indian Coconut J 22:7-9

Jeppson LR, Keifer HH, Baker EW (1975) Mites injurious to economic plants. University of California Press, Berkeley

Kane EC, Ochoa R, Erbe EF (2005) Raoiella indica Hirst (Acari: Tenuipalpidae): an island-hopping mite pest in the Caribbean. Abstract, ESA meeting, Fort Lauderdale, December 2005

Kane E, Ochoa R (2006) Detection and identification of the red palm mite Raoiella indica Hirst (Acari: Tenuipalpidae). USDA-ARS, Beltsville, p 6

Mendonca RS, Navia D, Flechtmann C (2005) Raoiella indica Hirst (Prostigmata: Tenuipalpidae), o acaro vermelho das palmeiras-uma ameaça para as Americas. EMBRAPA. Documentos 146, p 37

Mesa NC, Ochoa R, Welbourn WC, Evans GA, Moraes GJ (2009) A catalog of the Tenuipalpidae (Acari) of the World with a key to genera. Zootaxa 2098:1-185

Moutia LA (1958) Contribution to study of some phytophagous acarina and their predators in Mauritius. Bull Entomol Res 49:59-75

Nadarajan L, Channabasavanna G, Chandra BK (1990) Control of coconut pests through stem injection of systemic insecticides. Mysore J Agric Sci 14:355-364

Nagesha-Chandra BKN, Channabassanna GP (1984) Development and ecology of Raoiella indica Hirst (Acari: Tenuipalpidae) on coconut. In: Griffiths DA, Bowman CE (eds) Acarology VI, vol 2. Horwood, Chichester, pp 785-790

Navia D, Marsaro AL Jr, da Silva FR, Gondim MGC Jr, de Moraes GJ (2011) First report of the red palm mite, Raoiella indica Hirst (Acari: Tenuipalpidae), in Brazil. Neotrop Entomol 40:409-411

PROSEA (2006) Areca catechu. Agroforestry Tree Database. http://www.worldagroforestry.org/sea/ Products/AFDbases/af/asp/SpeciesInfo.asp

Puttaswamy, Rangaswamy HR (1976) Stethorus keralicus Kapur (Coleoptera: Coccinellidae), a predator of the areca palm mite. Curr Res 5:27-28

Rodrigues JCV, Antony LMK (2011) First report of Raoiella indica (Acari: Tenuipalpidae) in Amazonas State, Brazil. Fla Entomol 94:1073-1074

Rodrigues JCV, Ochoa R, Kane EC (2007) First report of Raoiella indica Hirst (Acari: Tenuipalpidae) and its damage to coconut palms in Puerto Rico and Culebra Island. Int J Acarol 33:3-5

Rodríguez H, Montoya A, Ramos M (2007) Raoiella indica Hirst (Acari: Tenuipalpidae): a threat for Cuba]. Revista de Protección Vegetal 22:142-153 (in Spanish)

Sakar PK, Somchodhury AK (1988) Evaluation of some pesticides against Raoiella indica Hirst on coconut palm in West Bengal. Pesticides 22:21-22

Sakar PK, Somchodhury AK (1989) Interrelationship between plant characters and incidence of Raoiella indica Hirst on coconut. Indian J Entomol 51:45-50

Saradamma K (1973) Evaluation of toxicity of some pesticides to the red mite on coconut, Raoiella indica (Hirst) (Phytoptipalpidae). Agric Res J Kerala 10:61-62

Sayed T (1942) Contribution to the knowledge of Acarina in Egypt: the genus Raoiella Hirst (Pseudotetranychinae: Tetranychidae). Bulletin Societe Fouad ler D'Entomologie 26:81-91

Somchoudhry AK, Sarkar PK (1987) Observations on natural enemies found in association with coconut mite, Raoiella indica Hirst. Bull Entomol 28:104-107

Vásquez C, de Quirós GM, Aponte O, Sandoval DMF (2008) First report of Raoiella indica Hirst (Acari: Tenuipalpidae) in South America. Neotrop Entomol 37:739-740

Zaher MA, Wafa AK, Yousef AA (1969) Biological studies on Raoiella indica Hirst and Phyllotetranychus aegyptiacus Sayed infesting date palm trees in U.A.R. (Acarina: Tenuipalpidae). Zeitschrift für angewandte Entomologie 63:406-411 